[Regular Paper]

\title{
Carboxylation of Cesium 2-Naphthoate in the Alkali Metal Molten Salts of Carbonate and Formate with $\mathrm{CO}_{2}$ under High Pressure
}

\author{
Kiyoshi Kudo*, Masahide Shima, Yasuhiko Kume, Futoshi Iкомa, \\ Sadayuki Mori, and Nobuyuki Sugrta
}

Institute for Chemical Research, Kyoto University, Gokanosho, Uji, Kyoto 611

(Received June 22, 1994)

\begin{abstract}
The carboxylation of alkali metal 2-naphthoate (2-NC) in mixed molten salts consisting of alkali metal carbonate and formate with $\mathrm{CO}_{2}$ under high pressure $(400 \mathrm{~atm})$ at temperature of $380^{\circ} \mathrm{C}$, was investigated. When cesium carbonate and formate were employed to prepare mixed molten salts, the reaction proceeded smoothly to give cesium naphthalenedi- and tri-carboxylates (NDC and NTC), and total yield of carboxyl group in the products exceeded that expected from disproportionation. Among the NDC isomers, the principal product was 2,6-naphthalenedicarboxylate (2,6-NDC). The effect of alkali metal species on the reactivity increased remarkably in the order $\mathrm{K}<\mathrm{Rb}<\mathrm{Cs}$. Lithium and sodium salts were quite inferior in this respect. The effects of the pressure of $\mathrm{CO}_{2}$, reaction temperature, and the amount of carbonate on the yield of carboxylated products were examined. Studies on the mechanism of the reaction with labeled ${ }^{13} \mathrm{CO}_{2}$ confirmed that an externally added $\mathrm{CO}_{2}$ is incorporated in the products.
\end{abstract}

\section{Introduction}

The cadmium halides-catalyzed rearrangement of potassium phthalate into terephthalate and the disproportionation of potassium benzoate into terephthalate and benzene are well known as the Henkel process. The reaction is confined not only to the salts of benzenecarboxylic acids, but similarly applied to other aromatic compounds. In the naphthalene series, Raecke reported that a potassium 1-naphthoate (1-NC) and 2-naphthoate (2-NC) disproportionates to 2,6-naphthalenedicarboxylate $\left.(2,6-\mathrm{NDC})^{1}\right)$. On the other hand, McNelis ${ }^{2)}$, Patton and Son ${ }^{3)}$, and Dozen ${ }^{4)}$ reported that sodium 1 - and $2-\mathrm{NC}$ could be transformed into 2,3-NDC. The Henkel reaction was usually carried out by using the potassium salts with $\mathrm{CO}_{2}$ under pressure in the range of 10 to $140 \mathrm{~atm}$, at temperature of $350-450^{\circ} \mathrm{C}$, in the presence of a catalytic amount of cadmium salt or sometimes zinc salt (Eq. (1)). Sodium and lithium carboxylates gave much lower yield at temperatures exceeding the usual range of 400 to $450^{\circ} \mathrm{C}^{5}$.

Recently, the rearrangement of dipotassium 1,8-NDC to 2,6-NDC isomer was reported by Mitamura et al. $\left.{ }^{6}\right)$. Moreover, they have published a report on the selective formation of 2,6-NDC

* To whom correspondence should be addressed. by transcarboxylation from dipotassium phthalate to naphthalene, in the presences of cesium and cadmium halides, in naphthalene dispersion medium ${ }^{7}$. The authors have also reported, independently, on cadmium iodide-catalyzed transcarboxylation of naphthalene to 2,6-NDC, using various alkali metal benzoates, in the presence of some cesium halides as co-catalyst and discussed the mechanism of combination of decarboxylation, proton abstraction, and recarboxylation $^{8}$. In the previous paper, we have reported already a mild and efficient carboxylation of potassium acetate to dipotassium malonate in mixed alkali metal molten salt, consisting of potassium carbonate and formate under with $\mathrm{CO}$ under pressure9). Now, we explored whether, or not, cesium carbonate-cesium formate mixed molten salt system is applicable to the synthesis of 2,6-NDC isomer by direct carboxylation of alkali metal 2-NC with $\mathrm{CO}_{2}$ under high pressure (Eq. (2)). From the preliminary study, it was found that cesium 2-NC gave a higher total yield of the carboxyl group in products than by disproportionation and the products composition was considerably more complicated than what would appear from the overall equation (Eq. (2)).

In the present paper, the carboxylation of cesium 2-NC with $\mathrm{CO}_{2}$ under high pressure was studied for comparison with previous studies. 

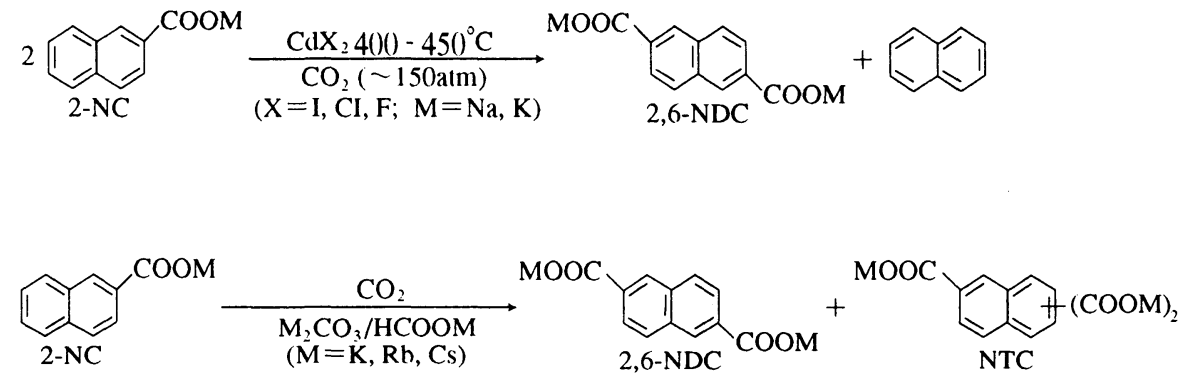

The role of cesium carbonate in the catalyst and the mechanism thereof are discussed also on the basis of effects of the reaction parameters and the results of the experiment using ${ }^{13} \mathrm{C}$-labeled $\mathrm{CO}_{2}$.

\section{Experimental}

\section{1. Materials}

Alkali metal salts of 2-NG and formates were prepared as follows: 2-NC or formic acid were neutralized with aqueous alkali metal hydroxides to $\mathrm{pH} 7-7.5$. The solutions were then evaporated to dryness and further dried under vacuum ( $c a$. $5 \mathrm{mmHg}$ ) at temperature in the range of 150 $180^{\circ} \mathrm{C}$. Alkali metal carbonates were obtained commercially, which were further dried before use. In order to analyze the products in the reaction mixture, commercially unavailable NDC isomers and naphthalenetricarboxylic acid (NTG) isomers were prepared by oxidation of the corresponding di- and trimethylnaphthalene isomers ${ }^{10}$. ${ }^{13} \mathrm{C}$ Labeled cesium carbonate $\left(99\right.$ atom $\%{ }^{13} \mathrm{C}$ ) and $\mathrm{CO}_{2}$ $\left(99\right.$ atom\% ${ }^{13} \mathrm{C}$ ) were obtained from MSD Isotopes in France.

\section{2. General Procedure}

A mixture of cesium 2-NG ( $1 \mathrm{mmol})$, cesium carbonate $(5 \mathrm{mmol})$ and cesium formate $(40 \mathrm{mmol})$ were mixed to a uniform dispersion in a mortar. The mixed powder was fed into a shaking-type autoclave $(c a .25 \mathrm{ml}$ ) and dried in vacuum at temperature of $120^{\circ} \mathrm{C}$ for $1 \mathrm{~h}$. After cooling to room temperature, a desired amount of liquid $\mathrm{CO}_{2}$ (16-18 g) was fed into the autoclave. The mixture was then heated to the desired temperature, where the warming-up period was $c a .20 \mathrm{~min}$, and thereafter it was maintained at the desired temperature for $4 \mathrm{~h}$. The pressure was increased to $400 \mathrm{~atm}$ at the reaction temperature. After cooling, the reaction mixture was collected, and dissolved in water. The alkaline aqueous solution was extracted with ether to remove naphthalene, the aqueous solution being acidified (to $\mathrm{pH}$ ) with hydrochloride acid to give free acids, which was sufficiently extracted with ether by salting-out technique, and then subjected to product analysis as outlined below.

\section{3. Analyses}

The mixed acids were esterified into corresponding methyl esters with diazomethane in etherdichloromethane solution, and analyzed by GC, using trans-stilbene as the internal standard at temperature of $250^{\circ} \mathrm{C}$ (column: Apiezon grease $\mathrm{L}$ on uniport HP). Further, the ether-soluble substance was analyzed by GC, using biphenyl as the internal standard at temperature rang of 140 $200^{\circ} \mathrm{C}$ (column: $\mathrm{OV}-1701$ capillary column, $0.25 \mathrm{~mm} \times$ $50 \mathrm{~m})$.

\section{Results and Discussion}

\section{1. Effect of Alkali Metal Species}

First, the reaction of 2-NG with $\mathrm{CO}_{2}$, using various alkali metal salts ( $\mathrm{M}: \mathrm{Li}, \mathrm{Na}, \mathrm{K}, \mathrm{Rb}$, and $\mathrm{Cs}$ ) and several combinations of alkali metal carbonate $\left(\mathrm{M}_{2} \mathrm{CO}_{3}\right)$ and formate (HCOOM) at temperature of $380^{\circ} \mathrm{C}$, under high pressure $(400 \mathrm{~atm})$, was examined. The results are summarized in Table 1. When lithium and sodium salts systems were employed (Runs 1 and 2), no carboxylation occurred, while potassium, rubidium, and cesium salts systems gave a mixture of NDG and NTC isomers in moderate yields. Among various alkali metal salts studied, cesium salt was the most effective, in following increasing order of effectiveness: $\mathrm{K}<\mathrm{Rb}<\mathrm{Cs}$. Although 2,6-NDC was obtained as the main product, in any case, the influence of the alkali metal on selectivity of 2,6-NDC was unexpectedly great, and the decreasing order was $\mathrm{K}<\mathrm{Rb}<\mathrm{Cs}$. These results may be explained in terms of the difference in thermal stability between these salts. Other products obtained as NDC isomers were 2,4- , 2,7-NDC, and small amounts of 2,3- and 1,2-NDC. In this reaction, the most remarkable features were that the amount of naphthalene generated was quite small, and that the total carboxylation yield $(R)$, which is defined 
Table 1 The Effect of Various Alkali Metal Species ${ }^{\text {a) }}$

\begin{tabular}{|c|c|c|c|c|c|c|c|c|c|}
\hline \multirow{2}{*}{ Run } & \multicolumn{3}{|c|}{ Alkali species (M) } & \multirow{2}{*}{$\begin{array}{c}\text { Conv. } \\
{[\%]}\end{array}$} & \multicolumn{3}{|c|}{ Products and yields [\%] ${ }^{\text {b) }}$} & \multirow{2}{*}{$R^{\mathrm{c})}$} & \multirow{2}{*}{$\begin{array}{c}\text { Select. of } \\
2,6-\mathrm{NDCN}^{\mathrm{g})}\end{array}$} \\
\hline & 2-NCM & $\mathrm{M}_{2} \mathrm{CO}_{3}$ & HCOOM & & $\mathrm{NDCN}^{\mathrm{d})}$ & NTCNe) & $N^{f)}$ & & \\
\hline 1 & $\mathrm{Li}$ & $\mathrm{Li}$ & $\mathrm{Li}$ & 2.6 & 0 & 0 & trace & - & \\
\hline 2 & $\mathrm{Na}$ & $\mathrm{Na}$ & $\mathrm{Na}$ & 4.5 & 0 & 0 & trace & - & \\
\hline 3 & $\mathrm{~K}$ & $\mathrm{~K}$ & $\mathrm{~K}$ & 9.5 & 5.1 & 1.0 & trace & 1.01 & 82.4 \\
\hline 4 & $\mathrm{Rb}$ & $\mathrm{Rb}$ & $\mathrm{Rb}$ & 28.0 & 12.4 & 10.9 & 1.0 & 1.12 & 78.2 \\
\hline 5 & Cis & Cs & Cs & 68.0 & 23.8 & 26.5 & 0.7 & 1.52 & 52.2 \\
\hline 6 & Cs & Cs & - & 81.3 & 8.6 & 43.9 & 0.5 & 1.70 & 73.3 \\
\hline 7 & Cs & - & Cs & 52.5 & 22.0 & 19.6 & trace & 1.50 & 48.2 \\
\hline 8 & Cs & - & - & 7.5 & 0.7 & 0.2 & 1.5 & 0.90 & 62.1 \\
\hline $9^{\text {h) }}$ & Cs & Cs & - & 4.2 & 0 & 0 & trace & 0.96 & - \\
\hline 10 & Cs & $\mathrm{K}$ & $\mathrm{K}$ & 10.6 & 5.2 & 1.9 & trace & 1.00 & 82.7 \\
\hline 11 & $\mathrm{~K}$ & Cs & $\mathrm{K}$ & 34.1 & 12.6 & 9.9 & 4.2 & 1.19 & 79.9 \\
\hline 12 & $\mathrm{~K}$ & $\mathrm{~K}$ & Cs & 76.5 & 29.6 & 35.3 & 0.8 & 1.79 & 64.1 \\
\hline
\end{tabular}

a) Reaction conditions: 2-NCM, $1 \mathrm{mmol} ; \mathrm{M}_{2} \mathrm{CO}_{3}, 5 \mathrm{mmol}$; $\mathrm{HCOOM}, 40 \mathrm{mmol}$; $\mathrm{CO}_{2}$ pressure, 400 atm; reaction temperature, $380^{\circ} \mathrm{C}$; reaction time, $4 \mathrm{~h}$. b) GC yield on the charged 2-NCM. c) The ratio of the number of carboxyl group in products to that of charged 2-NCM. d) Naphthalene dicarboxylate. e) Naphthalenetricarboxylate. f) Naphthalene. g) The selectivity of 2,6-naphthalenedicarboxylate based on the yield NDC. h) Under an argon atmosphere.

as the molar ratio of the total number of carboxyl group in the products to that of initial 2-NC, exceeded 1.0 (Runs 5-7 in Table 1 ). This result clearly indicates that the present reaction should be taken as a direct carboxylation of the cesium 2-NC with gaseous $\mathrm{CO}_{2}$ and should not be taken as disproportionation or rearrangement, as in the second Henkel reaction ${ }^{2)}$. Interestingly enough, when the reaction was carried out in the absence of the formate, as reaction medium, mainly NTC isomers were obtained along with small amounts of 2,3,6,7-naphthalenetetracarboxylate (NTEC) (Run 6). Principal products as NTG isomers were 2,4,6-, 1,3,5-, and 1,3,6-NTC of which the former predominate. The difference between those with and without formate as molten salt might be due to a dilution effect on the substrate and primary products (NDC). On the other hand, the reaction occurring without cesium carbonate, and NDG and NTC isomers resulted in the same extent (Run 7). This result shows that the reaction is caused with the cesium carbonate generated by decomposition of cesium formate as described later.

It should be noted that no carboxylation or disproportionation products were obtained in the absence of both carbonate and formate, even with $\mathrm{CO}_{2}$ under high pressure (Run 8), and also in the presence of cesium carbonate in argon atmosphere (Run 9). These results indicate that both alkali metal carbonate and $\mathrm{CO}_{2}$ are essential to obtain the present reaction. Real active species of the carboxylation must be alkali metal carbonates.

Each of potassium and cesium formates ( $\mathrm{mp} .160$ and $280^{\circ} \mathrm{C}$ ) melt under the present reaction conditions, and could operate as a solvent, promoting both heat and mass transfers in the reaction, in spite of their partial decomposition into hydrogen, carbon monoxide and carbonate.
The effect of combination of potassium and cesium salts of 2-NC, carbonate, and formate was examined in Runs 10-12. The reactivity of cesium and potassium 2-NC in $\mathrm{K}_{2} \mathrm{CO}_{3}-\mathrm{HCOOK}$ medium are comparable and lower than that of any other combination systems (Runs 10 and 3). This indicates that an alkali metal species of the substrate have no appreciable influence on the carboxylation. On the other hand, when cesium carbonate was used instead of potassium carbonate, the yields of NDC isomers increased with high selectivity of 2,6-NDC (Run 11). Among various combinations examined, $\mathrm{K}_{2} \mathrm{CO}_{3}$-HCOOCs system was recognized as the best system, judging from the yield of 2,6-NDC (Run 12).

For the purpose to optimize the reaction conditions and to obtain more details on the mechanism, the influence of the reaction parameters on the formation of the NDC and NTC isomers was studied, using the cesium salts system.

\section{2. Effects of the Reaction Temperature}

Shown in Table 2 are the effects of reaction temperature on the reaction of cesium 2-NC, for a series of 1 and $4 \mathrm{~h}$-experiments in $\mathrm{Cs}_{2} \mathrm{CO}_{3}$ HCOOCs molten system, where pressure of $\mathrm{CO}_{2}$ was fixed at $400 \mathrm{~atm}$. At lower temperature, $350^{\circ} \mathrm{C}$, much lower yield resulted. The yields of both NDC and NTC, and selectivity of 2,6-NDC increased remarkably with the rise in reaction temperature in the range of 350 to $420^{\circ} \mathrm{C}$. At $420^{\circ} \mathrm{C}$, even for $1 \mathrm{~h}$, the total yield exceeded that at $400^{\circ} \mathrm{C}$ for $4 \mathrm{~h}$, and NTC isomers produced preferentially. Furthermore, the $R$ value reached 2.01. At higher temperature, the rise in the selectivity of 2,6-NDC must be due to the rearrangement of thermally-unstable NDC isomers (such as 2,4and 2,7-NDC) to 2,6-NDC, which is the most thermally-stable isomer in analogy with terephthalate for the benzene nucleus. 
Table 2 Effect of Reaction Temperature ${ }^{a)}$

\begin{tabular}{|c|c|c|c|c|c|c|}
\hline \multirow{2}{*}{$\begin{array}{c}\text { Temp. } \\
{\left[{ }^{\circ} \mathrm{C}\right]}\end{array}$} & \multirow{2}{*}{$\begin{array}{l}\text { Time } \\
{[\mathrm{h}]}\end{array}$} & \multicolumn{3}{|c|}{ Yield [\%] ${ }^{\mathrm{b})}$} & \multirow[b]{2}{*}{$R^{\mathrm{c})}$} & \multirow{2}{*}{ Select. of $2,6-\mathrm{NDC}[\%]^{\mathrm{g}}$} \\
\hline & & NDC $^{d)}$ & $\mathrm{NTC}^{\mathrm{e})}$ & $N^{f)}$ & & \\
\hline 350 & 4 & 9.4 & 2.2 & 0.2 & 1.01 & 35.1 \\
\hline 380 & 1 & 12.4 & 2.2 & 2.3 & 1.17 & 33.1 \\
\hline 380 & 4 & 23.8 & 26.5 & 0.7 & 1.52 & 52.1 \\
\hline 400 & 1 & 25.1 & 15.3 & 0.6 & 1.36 & 39.0 \\
\hline 400 & 4 & 22.3 & 37.7 & 0.7 & 1.99 & 60.1 \\
\hline 420 & 1 & 24.5 & 37.5 & 1.3 & 2.01 & 61.0 \\
\hline
\end{tabular}

a) Conditions are identical to those in Table 1 without reaction temperature and time. b)-g) are the same as those in Table 1.

\section{3. Effect of Pressure of $\mathrm{CO}_{2}$}

In the Henkel reaction, it is known that both the rate and yield of disproportionation increase with pressure of $\mathrm{CO}_{2}$ over the range from $1 \mathrm{~atm}$ to $50 \mathrm{~atm}$. Detailed dependence on the pressure of $\mathrm{CO}_{2}$ concerning yields of product was examined over the range from $0 \mathrm{~atm}$ (under argon atmosphere) to about $500 \mathrm{~atm}$, as shown in Fig. 1. The most striking characteristic of the reaction is the yield curve for NDC isomer, which shows a double acceleration through a minimum at about $200 \mathrm{~atm}$. This phenomenon suggests that in the lower pressure range $(<200 \mathrm{~atm})$, since the reaction produces a significant amount of naphthalene, the formation of NDC isomers occurs through disproportionation, whereas in the range above $200 \mathrm{~atm}$ the direct carboxylation occurs by added $\mathrm{CO}_{2}$ on the nucleus of naphthoates. On the other hand, since the yield of NTC isomers increased gradually with the increase of the pressure in all ranges, some NTC isomers may have been produced by the subsequent carboxylation of

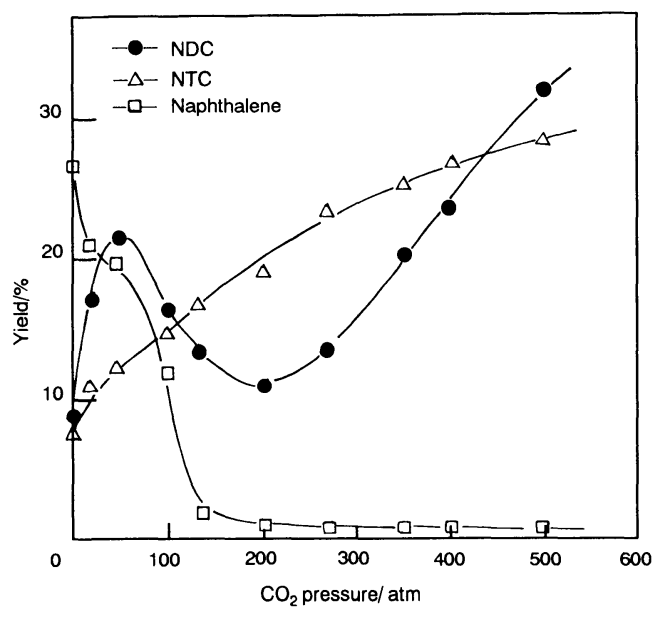

Cesium 2-NC, $1 \mathrm{mmol}$; $\mathrm{Cs}_{2} \mathrm{CO}_{3}, 5 \mathrm{mmol}$; HCOOCs, 40 mmol; $380^{\circ} \mathrm{C}: 4 \mathrm{~h}$.

Fig. 1 Effect of $\mathrm{CO}_{2}$ Pressure on the Carboxylation of Cesium 2-Naphthoate primary products. In the present reaction, a higher pressure above $200 \mathrm{~atm}$ is necessary to prevent the disproportionation of $2-\mathrm{NG}$ and to promote direct carboxylation.

\section{4. The Time-dependent Products Composi- tion}

Shown in Fig. 2a and 2b are typical diagrams depicting products composition vs. reaction time in the carboxylation of cesium 2-NC. At initial reaction stage (Fig. 2a), 2,4-NDC was produced in preference to 2,6- and 2,7-NDC isomer. The yield curves of both 2,4- and 2,7-NDC, however, have similar forms with maxima at the same time (ca. $1.5 \mathrm{~h}$ ) and then decreasing along with increase in the yields of 2,6-NDC and subsequent carboxylation products. The low yield of ortho-mono carboxylation product, 2,3-NDC, scarcely changed.

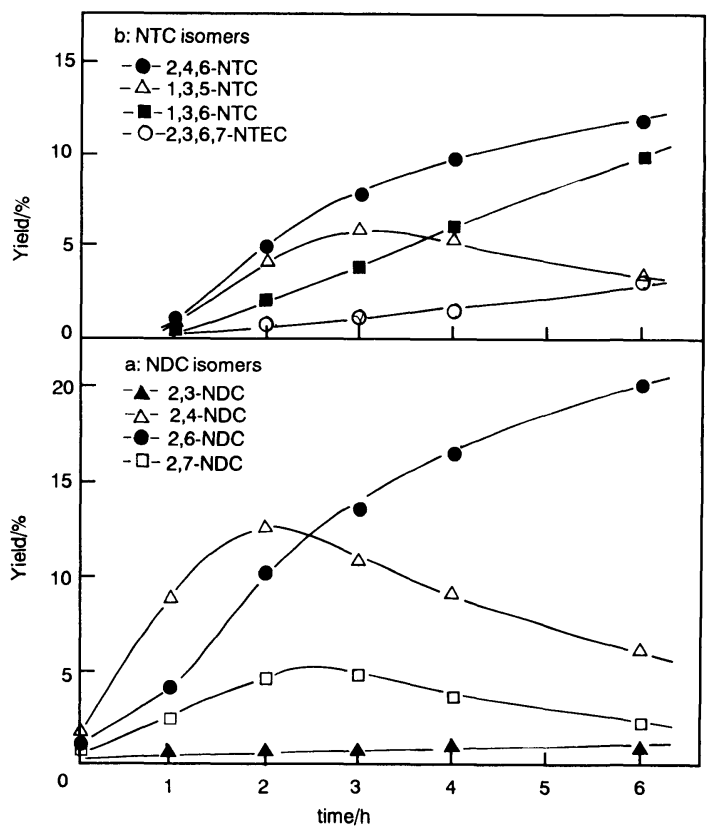

Cesium 2-NC, $1 \mathrm{mmol}$; $\mathrm{Cs}_{2} \mathrm{CO}_{3}, 5 \mathrm{mmol}$; HCOOCs, 40 mmol; $380^{\circ} \mathrm{C} ; 400 \mathrm{~atm}$.

Fig. 2 Carboxylation of Cesium 2-Naphthoate with $\mathrm{CO}_{2}$ under High Pressure 
In the subsequent stage (Fig. 2b), yields of 2,4,6-, 1,3,6-, and 1,3,5-NTC isomers and 2,3,6,7-NTEC were found first after about $\mathrm{l} \mathrm{h}$ induction period of reaction, and their yields gradually increased, except for 1,3,5-NTC. These findings indicate that the reaction includes the rearrangement of primary products, 2,4- and 2,7-NDG isomers, to 2,6 -NDC in the earlier stage, and subsequent carboxylation and/or cross-disproportionation between the unstable NDC isomers leading to the formation of NTC isomers and 2-NC in the later stage. It should be noted that the isomers described above are to the minimum extent; other NDC and NTD intermediate may have been formed, but the analytical method employed here (GC of methyl esters) precluded a sharp separation of all other isomers.

\section{5. Effect of $\mathrm{Cs}_{2} \mathrm{CO}_{3}$}

One striking feature of the present reaction is the use of $\mathrm{Cs}_{2} \mathrm{CO}_{3}$ as a base. Under identical conditions with $\mathrm{K}_{2} \mathrm{CO}_{3}$, which is a useful base in the Henkel reaction, the yield of carboxylated products was only $3.1 \%$. Table 3 shows the effects of the amount of $\mathrm{Cs}_{2} \mathrm{CO}_{3}$ on the reactivity, without the formate as the reaction medium. In the absence of the carbonate, the reaction scarcely occurred as described above. The yield and selectivity of products depended remarkably on the amount of
$\mathrm{Cs}_{2} \mathrm{CO}_{3}$. When the amount of $\mathrm{Cs}_{2} \mathrm{CO}_{3}$ was less than equimolar to the substrate, the yield was very low, and the reproducibility of the reaction was poor also. The yield of the carboxylated products increased with the amount of $\mathrm{Cs}_{2} \mathrm{CO}_{3}$. The best yield of 2,6-NDC was obtained at equimolar to the substrate. When the amount of $\mathrm{Cs}_{2} \mathrm{CO}_{3}$ exceeded about three times that of the substrate, NTC isomers were obtained as major products. The yield of NTG isomer was $43.9 \%, 75 \%$ of which was 2,4,6-NTC. This difference in reactivity from the $\mathrm{Cs}_{2} \mathrm{CO}_{3}$-HCOOCs molten system seems to be attributed to the physical state of the reaction mixture. In the 2-NC- $\mathrm{Cs}_{2} \mathrm{CO}_{3}$ non-molten system, both of the subsequent carboxylations and/or cross-disproportionation of the primary products to NTC isomers are more favorable than that in the molten system because of imperfect mass transfer. 3. 6. Reactions of Some Other Aromatic Acid Salts

Shown in Table 4 are the results of carboxylation of other aromatic acid salts by this procedure. When cesium 1-naphthoate (1-NC) was used, NDC and NTC isomers were obtained together with a considerable amount of naphthalene. This result indicates that $1-\mathrm{NC}$ is more thermally-unstable and easily disproportionated to stable 2,6-NDC and NTC isomers, even with $\mathrm{CO}_{2}$ under high pressure. 4-Biphenylcarboxylate was carboxylat-

Table 3 Effect of the Amount of $\mathrm{Cs}_{2} \mathrm{CO}_{3}{ }^{\text {a) }}$

\begin{tabular}{|c|c|c|c|c|c|}
\hline \multirow{2}{*}{$\begin{array}{l}\mathrm{Cs}_{2} \mathrm{CO}_{3} \\
{[\mathrm{mmol}]}\end{array}$} & \multicolumn{3}{|c|}{ Yield [\%] $]^{b)}$} & \multirow{2}{*}{$R^{\mathrm{c})}$} & \multirow{2}{*}{ Select. of $2,6-N D C[\%]^{\mathrm{g}}$} \\
\hline & $\mathrm{NDC}^{\mathrm{d})}$ & NTC ${ }^{e}$ & $N^{f)}$ & & \\
\hline 0 & 0.7 & 0.2 & 1.5 & - & - \\
\hline 0.5 & 13.6 & 5.6 & trace & 1.04 & 58.7 \\
\hline 1.0 & 22.7 & 11.2 & trace & 1.21 & 78.2 \\
\hline 3.0 & 11.5 & 42.0 & trace & 1.70 & 82.0 \\
\hline 5.0 & 8.6 & 43.9 & trace & 1.70 & 82.4 \\
\hline
\end{tabular}

Table 4 Carboxylation of Various Substrates ${ }^{\text {a) }}$

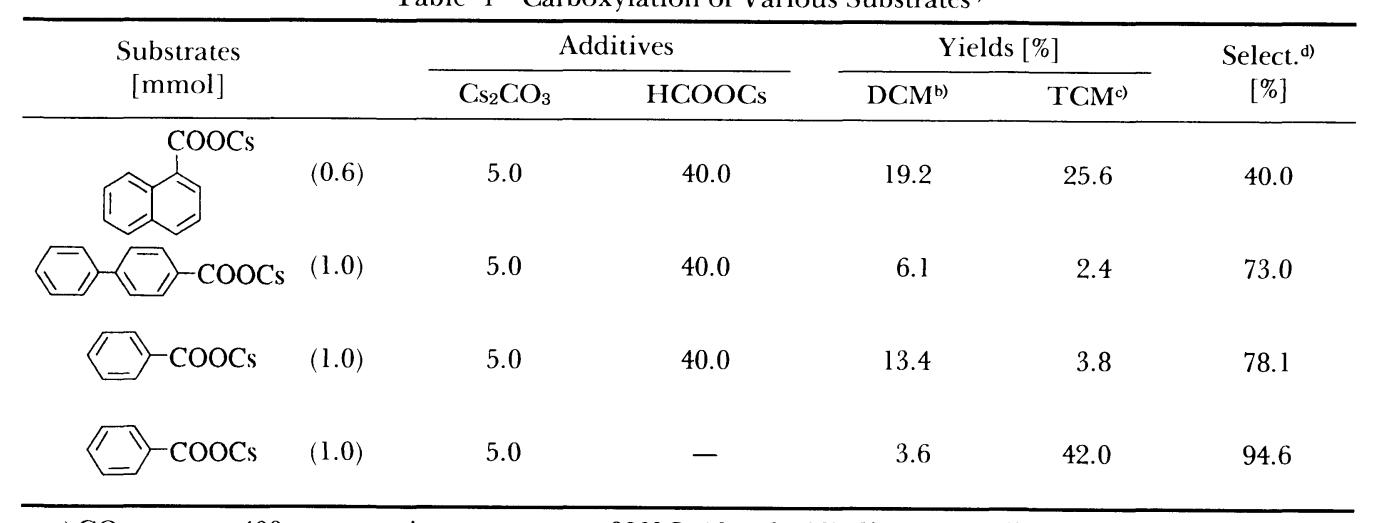

a) $\mathrm{CO}_{2}$ pressure $400 \mathrm{~atm}$; reaction temperature $380^{\circ} \mathrm{C} ; 4 \mathrm{~h}$. b) Alkaline metals dicarboxylate. c) Alkaline metals tricarboxylate. d) The selectivity of symmetrical dicarboxylate based on the substrates. 
ed ineffectively to produce 4,4'-biphenyldicarboxylate, while cesium benzoate was easily carboxylated into $\mathrm{di}$ - and tricarboxylate-isomers. The difference in productivities between reactions with and without formate was observed also in the case of cesium benzoate. In $\mathrm{HCOOCs}-\mathrm{Cs}_{2} \mathrm{CO}_{3}$ molten salt medium, dicarboxylate-isomers were obtained as the major products. In the reaction without formate, however, tricarboxylate isomers (mainly trimellitate) were produced as main products, a tendency similar to the case of 2-NC.

\section{7. Function of $\mathrm{Cs}_{2} \mathrm{CO}_{3}$ as a Reversible $\mathrm{CO}_{2}$ Carrier}

Hales et al. ${ }^{11)}$ reported that sodium phenoxide combines with an equimolecular amount of $\mathrm{CO}_{2}$ at room temperature to form an additional complex [PhONa.OCO], and that this complex is readily decomposed by water, and that the absorbed $\mathrm{CO}_{2}$ could be removed merely at $80^{\circ} \mathrm{C}$ in vacuo. The authors have confirmed the following facts: when a dry $\mathrm{Cs}_{2} \mathrm{CO}_{3}$ was kept in contact with $\mathrm{CO}_{2}$ under high pressure $(400 \mathrm{~atm})$ at temperature of $380^{\circ} \mathrm{C}$ for $2 \mathrm{~h}$, the solid product obtained gave $39.2 \%$ of cesium hydrogencarbonate $\left(\mathrm{CsHCO}_{3}\right)$ and $78.7 \%$ of $\mathrm{Cs}_{2} \mathrm{CO}_{3}$, after hydrolytic workup. Furthermore, when the solid product was heated again at $380^{\circ} \mathrm{C}$ in argon atmosphere for $1 \mathrm{~h}, \mathrm{CO}_{2}$ liberated was $19.6 \%$ (based on the initial $\mathrm{Cs}_{2} \mathrm{CO}_{3}$ ) and $\mathrm{Cs}_{2} \mathrm{CO}_{3}$ recovered was almost the same $(97.5 \%)$. On the other hand, potassium carbonate gave only $1.2 \%$ of $\mathrm{KHCO}_{3}$, and $96.5 \%$ of the potassium carbonate was recovered by the same procedure. These observations clearly indicate that the cesium carbonate and $\mathrm{CO}_{2}$ form a complex, $[\mathbf{X}]$, giving two equivalent amounts of $\mathrm{Cs}_{4} \mathrm{HCO}_{3}$ by hydrolysis (Eq. (3) and (4)).

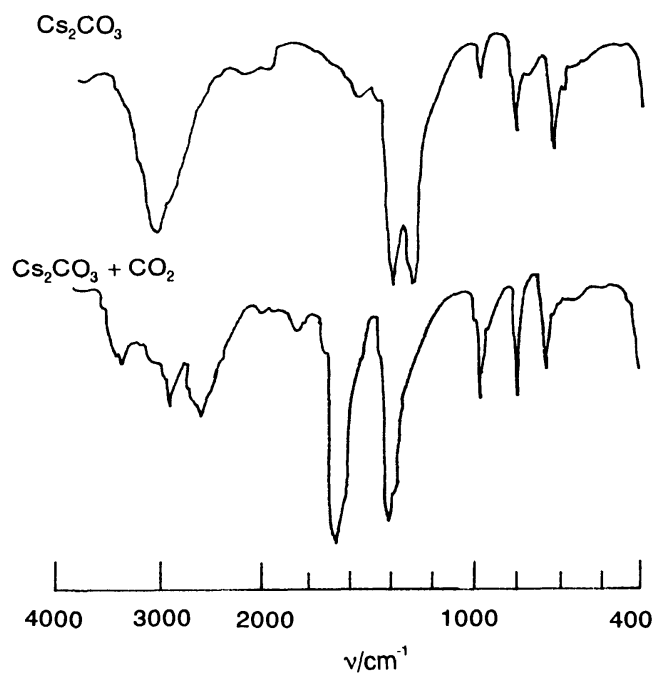

Fig. 3 IR Spectra of $\mathrm{Cs}_{2} \mathrm{CO}_{3}+\mathrm{CO}_{2}$ and $\mathrm{Cs}_{2} \mathrm{CO}_{3}$

$$
\begin{aligned}
& \mathrm{M}_{2} \mathrm{CO}_{3}+\mathrm{CO}_{2} \frac{400 \mathrm{~atm}}{380^{\circ} \mathrm{C} / 2 \mathrm{~h}} \underset{[\mathbf{X}]}{\left[\mathrm{M}_{2} \mathrm{CO}_{3} \cdot \mathrm{CO}_{2}\right]} \\
& {[\mathbf{X}]+\mathrm{H}_{2} \mathrm{O} \longrightarrow 2 \mathrm{MHCO}_{3}}
\end{aligned}
$$

In addition, the complexation of $\mathrm{CO}_{2}$ with $\mathrm{Cs}_{2} \mathrm{CO}_{3}$ was also ascertained by IR investigations. Figure 3 shows the IR spectra of the carbonate reacted compared with an authentic $\mathrm{Cs}_{2} \mathrm{CO}_{3}$. The carbonate reacted exhibits a new strong absorption at $1,660 \mathrm{~cm}^{-1}$, similar to those of sodium and potassium phenoxide- $\mathrm{CO}_{2}$ additional complex $\left(1,685 \text { and } 1,645 \mathrm{~cm}^{-1} \text {, respectively }\right)^{11), 12)}$ which is assignable to a carbonyl stretching $\nu(\mathrm{C}=\mathrm{O})$ and is diagnostic for the $\mathrm{CO}_{2}$ complexed with an alkali metal compound. Although the form of the complex $[\mathbf{X}]$ has not been determined in detail as yet, the complexation modes of $\mathrm{CO}_{2}$ can be assumed as follows:

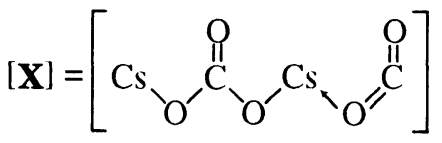

This structure is closely related to that of [PhOM. $\mathrm{CO}_{2}$ ] complex. Thus, the carbon-oxygen bond of the $\mathrm{CO}_{2}$ molecule in the complex $[\mathbf{X}]$ is an unusual state (in activated state, so to say).

\section{8. Mechanistic Studies with Labeled ${ }^{13} \mathrm{CO}_{2}$ and $\mathrm{Cs}_{2}{ }^{13} \mathrm{CO}_{3}$}

To ascertain the origin of the carboxyl group in the product (2,6-NDC), the reactions of cesium 2$\mathrm{NC}$ with ${ }^{13} \mathrm{C}$-labeled $\mathrm{CO}_{2}$ (i.e. $\left.{ }^{13} \mathrm{CO}_{2}\right)$, and that with ${ }^{13} \mathrm{C}$-labeled cesium carbonate (i.e. $\mathrm{Cs}_{2}{ }^{13} \mathrm{CO}_{3}$ ) were examined respectively under high pressure $(400$ atm) at temperature of $380^{\circ} \mathrm{C}$. When cesium 2$\mathrm{NC}$ was heated with $\mathrm{Cs}_{2}{ }^{13} \mathrm{CO}_{3}$ and ${ }^{12} \mathrm{CO}_{2}$ under high pressure (Eq. (5)), no appreciable amount of labeled products could be detected by GC-MS technique. On the other hand, the reaction with ${ }^{13} \mathrm{CO}_{2}$ under high pressure revealed that ${ }^{13} \mathrm{CO}_{2}$ was incorporated in the carboxyl group of the products (Eq. (6)), and practically no carboxyl group of the recovered 2-NC was exchanged with ${ }^{13} \mathrm{CO}_{2}$. In 2,6-NDC isomers, labeled 2,6-NDC isomers (EI and EII) and nonlabeled 2,6-NDC (EIII) were detected in the ratio of about 2:2:1 (Table 5). These results indicate that the carbon atom of the incorporated carboxylate group in the products is clearly derived from external $\mathrm{CO}_{2}$ gas, and the complicated exchange of the carboxyl groups occurs in the couse of the rearrangement of the unstable NDC isomers and/or transcarboxylation of 2-NC with the unstable NTC isomers to afford stable 2,6-NDC (see Scheme 1). 
Table 5 Reaction with ${ }^{13} \mathrm{CO}_{2}$ : Mass Spectrometric Investigations ${ }^{\text {a) }}$

\begin{tabular}{|c|c|c|c|c|}
\hline \multirow[t]{2}{*}{$\begin{array}{l}\text { Fragments } \\
\text { m.e }\end{array}$} & \multicolumn{2}{|c|}{ COOMe } & \multicolumn{2}{|c|}{$\mathrm{MeOOC}(2,6-\mathrm{NDC})$} \\
\hline & Authentic & Recovered & Authentic & Recovered \\
\hline $\mathbf{M}^{+}$ & $\begin{array}{l}186(64.2) \\
187(8.5)\end{array}$ & $\begin{array}{l}186(54.3) \\
178(13.7)\end{array}$ & $\begin{array}{l}244(59.3) \\
245(9.8)\end{array}$ & $\begin{array}{l}244(16.4) \\
245(37.5) \\
246(36.6)\end{array}$ \\
\hline $\mathrm{M}^{+}-\mathrm{OCH}_{3}$ & $\begin{array}{l}155(100) \\
156(13.6)\end{array}$ & $\begin{array}{l}155(100) \\
156(24.1)\end{array}$ & $\begin{array}{l}213(100) \\
214(17.1)\end{array}$ & $\begin{array}{l}213(100) \\
214(62.1) \\
215(62.9)\end{array}$ \\
\hline
\end{tabular}

a) Intensities in parentheses.
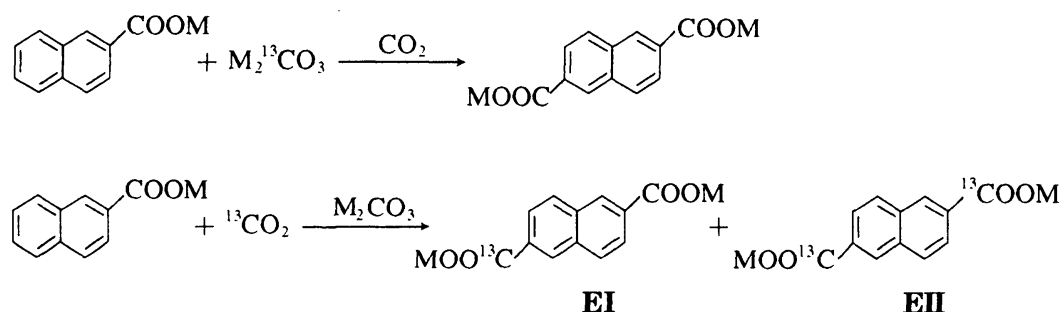<smiles>[X]OC(=O)c1ccc2cc(C(=O)OC)ccc2c1</smiles>

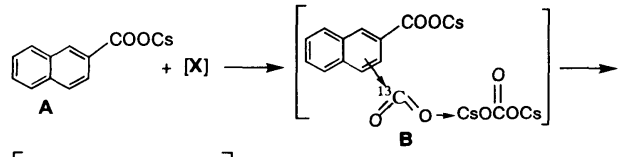

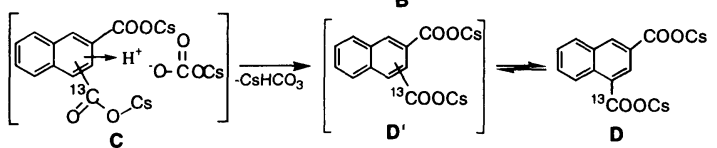

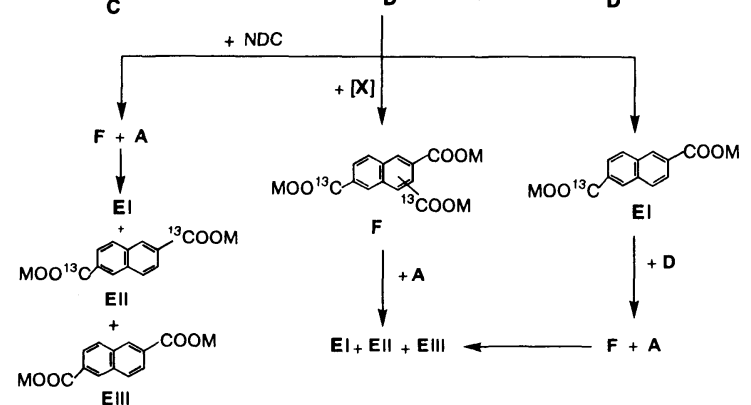

Scheme 1

It is noteworthy that the exchange does not occur between the added $\mathrm{CO}_{2}$ and the carboxylic group of substrate $(2-\mathrm{NC})$ during the reaction as mentioned above. Therefore, the mechanism proposed by McNelis ${ }^{2)}$ for the conversion of potassium 2-NG to 2,6-NDC, naphthoate (2-NC) involves a primary act of decarboxylation to a naphthalene anion, must be discarded.

Although, a complete mechanical elucidation of the reaction would be extremely difficult because of the diversity of the products. As for the formation of 2,6-NDC, we proposes a possible mechanism consisting of cesium carbonate-promoted carboxylation, depicted in Scheme 1.

The reaction begins with an activation of $\mathrm{CO}_{2}$ through formation of complex compound with the cesium carbonate (Eq. (3)), similar to that proposed for alkali metal phenoxide- $\mathrm{CO}_{2}$ complex ${ }^{11)}$. The complex $[\mathbf{X}]$ acts as a reversible $\mathbf{C O}_{2}$ carrier and activator. The complex $[\mathbf{X}]$ is then reacted with 2-NC to form an intermediate $\mathbf{B}$ and then $\mathbf{C}$, in which the substitution of $\mathrm{CO}_{2}$ onto the nucleus carbon of the naphthoate occurs in concert with abstraction of the hydrogen of 2-NC by the cesium carbonate which is partially polarized by the chelation of $\mathrm{CO}_{2}$. The driving force of this reaction may be attributed to the high coordination ability of the cesium species. The $\alpha$ hydrogen of the naphthalene ring, which is more reactive than $\beta$-hydrogen, is abstracted, and $\pi$ complex (D') is formed as key intermediate which is at equilibrium with $2,4-\mathrm{NDC}(\mathbf{D})$. The primary product $\mathbf{D}$, which have a thermally unstable $\alpha$ carboxyl group, may then be rearranged to the 
thermally stable 2,6-NDC( $(\mathbf{E})$ and/or crossdisproportionated into 2-NC and NTD isomers. The transcarboxylation between the NTC isomers (F) and 2-NC (A) then takes place leading to 2,6NDC, similarly to the reaction of potassium benzoate with potassium tricarboxylates ${ }^{13)}$. The combination of these reactions seems to result in the complex products.

Although the experimental results described above show that the decarboxylation-recarboxylation mechanism ${ }^{13}$ ) is not tenable, this does not rule out the possibility that the primary decarboxylation of the 2-NG may still represent the first step in the reaction.

\section{References}

1) Raecke, B., Angew. Chem., 70, 1 (1958)
2) McNelis, E., J. Org. Chem., 30, 1209 (1965).

3) Patton, J. W., Son, M. O., J. Org. Chem., 30, 2869 (1965).

4) Dozen, Y., Bull. Chem. Soc. Jpn., 41, 664 (1968).

5) Matsuoka, K., Kitao, F., Konishi, K., Kogyo Kagaku Zasshi, 74, 77 (1971).

6) Fujishiro, K., Mitamura, S., Bull. Chem. Soc. Jpn., 62, 786 (1989).

7) Kata, Y., Mitamura, S., International Congress of Pacific Basin, Dec., 1989, Honolulu, Abstr. Org. 405.

8) Kudo, K., Mori, S., Sugita, N., Bull. Inst. Chem. Res., Kyoto Univ., 70, 284 (1992).

9) Kudo, K., Sugita, N., Takezaki, Y., Nippon Kagaku Kaishi, 6, 1082 (1973).

10) Dozen, Y., Fujishima, S., Shingu, H., Thermochim. Acta., 25, 209 (1978).

11) Hales, J. L., Idnes Jones, J., Lindsey, A. S., J. Chem. Soc., 1954, 3145

12) Hirao, I., Kito, T., Bull. Chem. Soc. Jpn., 46, 3470 (1973).

13) Sorm, F., Ratusky, J., Chem. \& Ind., 1958, 294; 1966, 1798.

要旨

\title{
高圧二酸化炭秦下，ギ酸-炭酸アルカリ金属溶融塩中における 2-ナフトエ酸塩のカルボキシル化反応
}

\author{
工藤 清, 島 昌秀, 久米康仁, 生駒太志, 森 貞之, 杉田信之 \\ 京都大学化学研究所, 611 京都府宇治市五ヶ生
}

\footnotetext{
高圧二酸化炭素下，ギ酸-炭酸アルカリ金属溶融塩中におけ る2-ナフトエ酸塩のカルボキシル化反応を検討した。アルカ リ金属種による反応性を調べた結果, セシウム塩系が最も高く, セシウム>ルビジウム>カリウムの順に低くなり，ナトリウム およびリチウム塩系ではほとんど反応しなかった。ギ酸セシウ ム-炭酸セシウム溶融塩中, 400 気圧, $380^{\circ} \mathrm{C}$, セシウム $2-$ ナ フトエ酸塩のカルボキシル化反応ではナフタレンジカルボン酸 塩およびトリカルボン酸塩が容易に得られ, ジカルボン酸塩中
}

では 2,6-ジカルボン酸が主生成物であった。この反応での生 成物中の全カルボキシル基収率は不均化反応の值よりも大き く, しかもナフタレンの生成がほとんど見られず, 従来のヘン ケル法と違った結果が得られた。そこで,この反応の生成物収 率に及ぼす二酸化炭素圧力, 温度, および炭酸塩の添加量の効 果を調べた。 ${ }^{13} \mathrm{C}$ で標識した二酸化炭素を用いた反応結果, 加 圧二酸化炭素による直接カルボキシル化反応が進行しているこ とが明らかとなり，その反応機構について考察を行った。

\section{Keywords}

Carbon dioxide, Cesium naphthoate, High pressure, Direct carboxylation, Solid base catalyst, Cesium carbonate 